\title{
Helianthus annuus-A NEW IMPORTANT ELEMENT OF THE NON-ARABLE AND ARABLE FLORA IN SERBIA'S REGION OF SOUTHERN BANAT
}

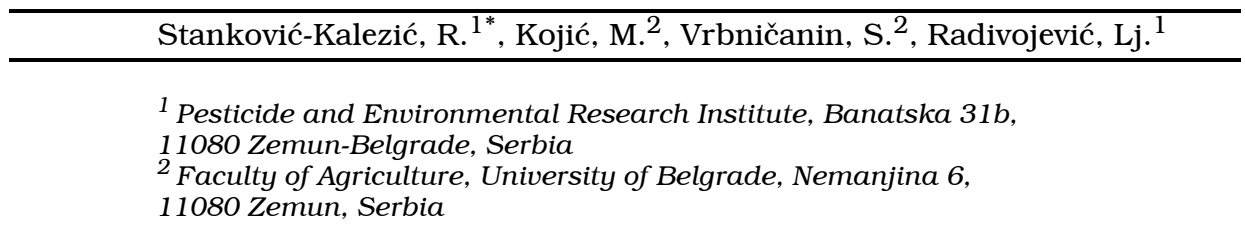

Received: March 10, 2007 Accepted: June 25, 2007

SUMMARY

Four species of the Helianthus genus have been found in the non-arable and arable communities in Vojvodina and Serbia, namely: $H$. annuus, $H$. tuberosus, $H$. decapetalus and $H$. scaberimus. Studies conducted hitherto have shown that Helianthus annuus has the highest frequency in all weed phytocoenoses examined so far. The spreading of $H$. decapetalus and $H$. scaberimus, introduced to Vojvodina from the neighboring Hungary and Romania, has still not assumed alarming proportions in quantitative terms, but a tendency has been observed of their further spreading. It is therefore necessary to monitor and study the trend of their expansion over the coming period.

Key words: Helianthus species, non-arable and arable flora, Vojvodina

\section{INTRODUCTION}

Invasive species that are being introduced to and are spreading across the Balkan Peninsula are becoming an important element of the non-arable and arable land in Serbia, and more importantly in the Vojvodina Province. Over the past several decades, some sporadic or altogether new species have assumed an increasingly important role in the region (Vrbničanin et al., 2004; Malidža and Vrbničanin, 2006). For example, Ambrosia artemisiifolia, which first appeared on the territory of the former Yugoslavia over half a century ago, is today a highly-frequent non-arable weed species, which has become a serious ecological threat (Kovačević, 1957, Veljković, 1994; Mataruga et al., 2004). Species of the genus Helianthus (Josifović, 1975) are important representatives of alien species in Serbia's non-arable and weed flora. The sunflowers (Helianthus species) are members of the plant family Compositae (Aseraceae). Hence, what one may think of as a sunflower "flower" is

* Corresponding author, Phone: ++381 11307 6133, Fax: ++381 11307 6133; e-mail: radmilast@sbb.co.yu 
actually a composite from a few to several hundred small but complete flowers (florets) (Rogers et al., 1981). The Helianthus genus has around 108 species in their original habitats on the American continent. The stems of all North American sunflowers are herbaceous (annuals and perennials), but is South America there are some four or five true shrubs (Watson, 1929). Helianthus species fall into several sections (Annui, Ciliares, Divaricati) and a number of series based on genetic and morphological characteristics (Heiser et al., 1969; Rogers et al., 1981).

Helianthus species have become increasingly frequent in the Vojvodina Province. In the vicinity of Novi Sad and the region of Bačka, Boža (1979) had identified Helianthus species such as $H$. decapetalus and $H$. scaberimus, and wild forms of $H$. tuberosus and H. annuus. Helianthus annuus belongs to the Rubri, i.e., the species with red or purple lobes of the disc corollas. The common sunflower, $H$. annuus comprises three main races: $H$. annuus ssp. lenticularis, the „wild“ sunflower; $H$. annuus ssp. annuus, the „weed“ sunflower; and $H$. annuus ssp. macrocarpus, the giant sunflower cultivated for its edible seeds. The weed sunflower is branched, but with large heads, achenes and more numerous rays than the wild race (Heiser, 1955). Many species are directly cross-compatible with cultivated $H$. annuus (Thompson et al., 1981). The other three species belong to the Flavi group, i.e., the species with yellow or brownish-yellow lobes of the disc corollas (Watson, 1929). Rađenović (1978) also reported of the presence of wild sunflower as a weed species in the Kosovo Province fields. This study aimed to determine the distribution of Helianthus annuus in non-arable areas and in arable fields of southern Banat.

\section{MATERIALS AND METHODS}

The study area of Pančevački rit (southern Banat) is situated in the Vojvodina Province, a region of intensive agricultural production. Research was conducted employing the Braun-Blanquet method (1964) in various non-arable habitats and in row crops (maize and sugar beet) over a number of years. Examination of the nonarable vegetation was conducted throughout the vegetation period, and phytocoenological surveys were mostly done over the entire area of each non-arable stand. In untreated maize and sugar beet crops, most surveys were done on $50-100 \mathrm{~m}^{2}$ relevés.

Coverage gives a much clearer idea of the relations and roles of individual species within a plant community than it is the case with the degree of presence, whose I-V index scale serves to show the presence of any particular species within an analyzed community. Computation of these indexes is described in detail in a publication on methodology by Braun-Blanquet (1964).

\section{RESULTS}

Four Helianthus species have been identified in the non-arable and arable communities in Vojvodina and Serbia so far: $H$. annuus, $H$. tuberosus, $H$. decapetalus and $H$. scaberimus. Of these, Helianthus annuus was found to dominate all of the 
weed phytocoenoses studied. Helianthus annuus, the cultivated sunflower run wild, was also found to be the most frequent of these species in the non-arable and arable areas of southern Banat.

The investigation conducted in cultivated maize and sugar beet fields at Pančevački rit confirmed the presence of Helianthus annuus in the local weed community. Table 1 shows the presence of $H$. annuus in maize over the 1996-2002 period with a uniformly high degree of coverage (III) varying between 105 and 693 .

Table 1: Degree of presence and coverage of Helianthus annuus in the weed communities of maize in Southern Banat

\begin{tabular}{lcc}
\hline Year & Degree of presence & Coverage \\
\hline 1996 & III & 105 \\
1997 & III & 230 \\
1998 & III & 107 \\
1999 & IV & 184 \\
2000 & III & 693 \\
2001 & III & 370 \\
2002 & III & 131 \\
\hline
\end{tabular}

Table 2 shows the presence of $H$. annuus in sugar beet over the 1996-2001 period. There is an evident similarity between the degrees of presence existing in sugar beet and in maize, while coverage values are somewhat lower in the former (190-405).

Table 2: Degree of presence and coverage of Helianthus annuus in the weed communities of sugar beet in Southern Banat

\begin{tabular}{lcc}
\hline Year & Degree of presence & Coverage \\
\hline 1996 & III & 314 \\
1997 & III & 405 \\
1998 & III & 231 \\
2000 & II & 190 \\
2001 & III & 200 \\
\hline
\end{tabular}

Table 3: Participation of Helianthus annuus in the non-arable communities of Southern Banat

\begin{tabular}{|c|c|c|c|c|c|c|}
\hline Association & 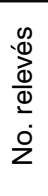 & 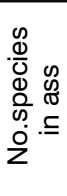 & 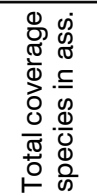 & 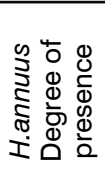 & 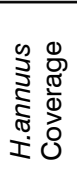 & 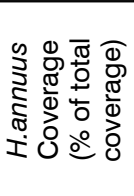 \\
\hline Ass. Matricario-Helianthetum annuuae & 8 & 60 & 11018 & $\mathrm{~V}$ & 5439 & 49.36 \\
\hline Ass. Artio-Artemisetum vulgaris & 19 & 123 & 14775 & III & 385 & 2.61 \\
\hline Ass. Sambucetum ebili & 7 & 53 & 16541 & II & 253 & 1.53 \\
\hline Ass. Lolio-Plantaginetum majoris & 7 & 73 & 13740 & IV & 77 & 0.56 \\
\hline Ass. Convolvulo-Agropyretum repentis & 25 & 119 & 14757 & II & 66 & 0.45 \\
\hline Ass. Bromo-Hordeteeum murali & 7 & 56 & 13867 & I & 1 & 0.02 \\
\hline
\end{tabular}


Analyzing the research reported by Ivanović (2000) on the weed community of Hibisco-Eragrostietum megastachyae Tx. (1950) in maize and sugar beet in southwestern Banat, we discovered a high degree of presence and coverage of Helianthus annuus there, which is in full agreement with our findings.

Investigating the non-arable vegetation of Pančevački rit, we found Helianthus annuus in 6 non-arable communities (Table 3). The degree of presence varied between I and V, while coverage had a wide range of 1 to 5439. Analyzing the communities with broad-leaf species predominating, we found a high coverage of $H$. annuus of 253-5439, i.e., 1.53 do $49.36 \%$ coverage. The highest degree of presence of $H$. annuus was found to be in the association Matricario-Helianthetum annuuae, where it is the dominant species (Figure 1). In grass communities, the presence of $H$. annuus was $1-77$, which is below $1 \%$ plant coverage.

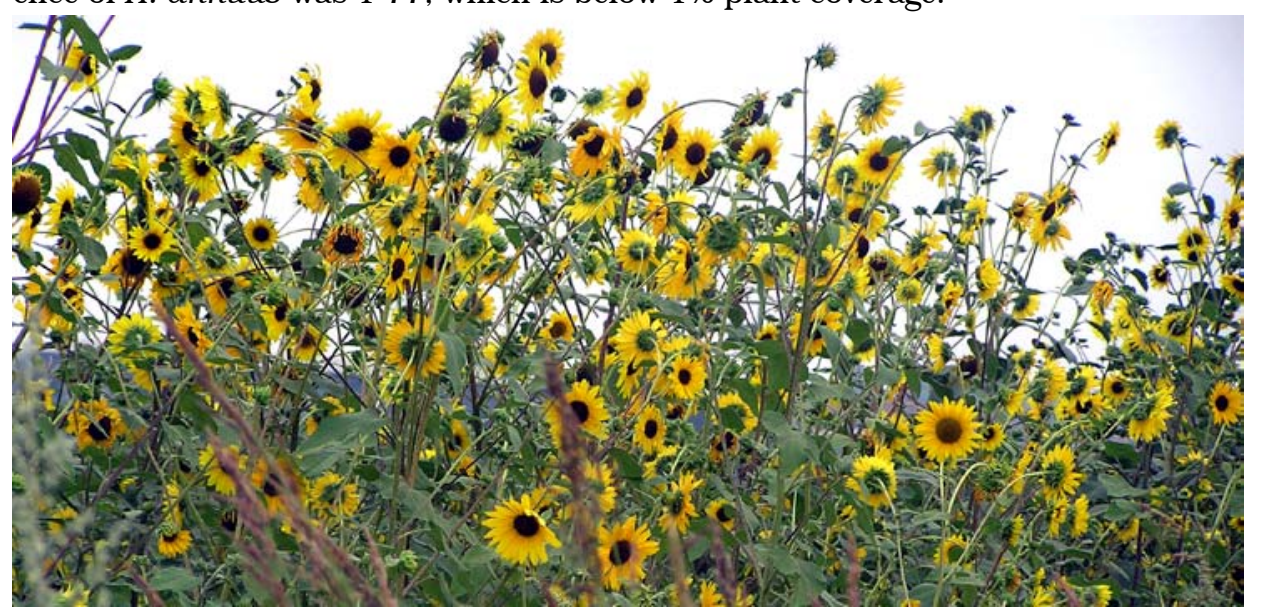

Figure 1: Association Matricario-Helianthetum annuuae

\section{DISCUSSION}

Preliminary results show that wild sunflower has a prominent place in the nonarable communities of southern Banat, and a growing influence on arable communities. The following invasive weed species have become highly frequent in recent times: Abutilon theophrasti L., Amaranthus retroflexus L., Chenopodium album L., Cirsium arvense (L.) Scop., Convolvulus arvensis L., Datura stramonium L, Solanum nigrum L., Sorghum halepense (L.) Pers., Setaria glauca (L.) Beauv., S. viridis (L.) Beauv. and Cannabis sativa L., while Helianthus annuus (StankovićKalezić et al., 2004) has lately assumed a prominent place. According to other reports (Boža, 1979, Merkulov and Boža, 1980) and our own investigation on the territory of southern Banat and across Vojvodina, four species of the Helianthus genus comprise the weed vegetation of the area, namely:

1. Helianthus annuus L. -wild form

2. Helianthus tuberosus L. -wild form

3. Helianthus decapetalus $\mathrm{L}$. 


\section{Helianthus scaberimus L.}

The data indicate that species of the genus Helianthus have an exceptionally important role in the non-arable and arable communities of Vojvodina. Expansion of the species $H$. decapetalus and $H$. scaberimus, introduced to Vojvodina from the neighboring Hungary and Romania, has still not assumed alarming proportions in quantitative terms, but a tendency of progressive expansion has been observed.

Our work focused on analyzing the relevant quantitative indicators relating to the species Helianthus annuus. According to the present situation, the species may be considered the most frequent and most aggressive sunflower species in non-arable areas and in field crops in the territory of southern Banat and the region of Vojvodina. Due to its considerable above-ground biomass and high plant numbers in arable phytocoenoses, Helianthus annuus has become a growing ecological issue over the years, so that further consideration of modalities of its successful control are now required. At present, other Helianthus species (H. tuberosus, H. decapetalus and $H$. scaberimus) do not pose a pressing problem, but their participation in the weed vegetation of the region may also be expected to increase over the coming years. Consequently, there is a need to monitor and analyze the movement of the populations of some sunflower species in southern Banat and in other parts of Vojvodina and Serbia, with the purpose of working out a most adequate and rational method of suppressing their expansion.

\section{REFERENCES}

Boža, P., 1979. Dve nove adventivne vrste roda Helianthus u flori Novog Sada (in Serbian). Matica Srpska Periodical for Natural Sciences 56: 5-71.

Braun-Blanquet, J., 1964. Grundzuge der Vegetationskunde. 3 Aufl. Springer, Wien.

Heiser, Jr., C.B., 1955. The Origin and Development of the Cultivated Sunflower. American Biology Teacher 1:161-167.

Heiser, Jr., C.B., Smith, D.C., Clevenger, S.B. and Martin, Jr., W.C., 1969. The North American Sunflowers (Helianthus). Mem.Torry.Bot.Club. 22(3): 1-218.

Ivanović, M., 2000. Građa i primena korovske zajednice okopavina u usevima intezivne primene herbicida $u$ jugozapadnom Banatu (in Serbian). Ph.D. Thesis, Faculty of Agruculture, University of Novi Sad, pp. 1-193.

Josifović, M., 1975. Flora Srbije (in Serbian), VII Tom, SANU, Srbija.

Jovanović, S., 1994. Ekološka studija non-arablene flore i vegetacije Beograda (in Serbian). Biološki fakultet Univerzitet u Beogradu, pp. 1-222.

Kovačević, J., 1957. Rasprostranjenost severnoamerickog korova limuncuka (Ambrosia artemisiifolia L.) u korovskim fitocenosama Srednje Posavine (in Serbian). Glasnik biološkog instituta u Sarajevu 1-2: 173-176.

Malidža, G. i Vrbničanin, S., 2006. Novo nalazište alohtone korovske vrste Ambrosia trifida L. na području Vojvodine (in Serbian). VIII Savetovanje o zaštiti bilja, Zbornik rezimea, Zlatibor, pp. 44-45

Mataruga, D., Janjić, V. i Mitrić S., 2004. Mogućnost suzbijanja ambrozije (Ambrosia artemisiifolia L.) foliarnim herbicidima (in Serbian). Acta biologica Iugoslavica, serija G: Acta herbologica 13(2): 88-95.

Merkulov, Lj. i Boža, P., 1980. Anatomske razlike kao taksonomski karakteri kod vrsta Helianthus decapetalus L. i Helianthus rigidus (Cass.) Desf. (Asteraceae) (in Serbian). Posebno izdanje iz Zbornika radova PMF-Novi Sad, 10: 303-310. 
Veljković, B., 1996. Rasprostranjenost novounetih korovskih vrsta Ambrosia artemisiifolia L i Iva xantithfolia Nutt. u Jugoslaviji (in Serbian). Knjiga radova V kongresa o korovima, Banja Koviljača, pp. 351-363.

Radjenović, B., 1978. Divlji suncokret -Helianthus annuus-non-arableis-Venzeljr. B. nova korovska biljka na poljima Kosova (in Serbian). Fragmeta herbologica Jugoslavica 96: 23-28.

Rogers, C.E., Thompson, T.E. and Seiler, G.J., 1981. Sunflowers Species of the United States. pp. 1-75.

Vrbničanin, S., Karadžić, B. i Dajić Stevanović, Z., 2004. Adventivni i invazivni korovi na području Srbije (in Serbian). Acta biologica Iugoslavica, serija G: Acta herbologica 13(1): $18-27$.

Stanković-Kalezić, R., Vrbničanin, S., Radivojević, Lj. and Gajević, D., 2004. Invading weed species on south part of Banat. Plant Protection Towards the $21^{\text {st }}$ Century, Beijng, China, Proc. $15^{\text {th }}$ International Plant Protection Congress, pp. 581.

Thompson, T.E., Zimmerman, D.C. and Rogers, C.E., 1981. Wild Helianthus as a genetic resource. Field Crops Research 4: 333-343.

Watson, E.E., 1929. Contributions to a monograph of the genus Helianthus. Papers Mich. Acad. Sci., Arts and Letters 9: 305-475.

\title{
Helianthus annuus-NUEVO ELEMENTO IMPORTANTE DE LA FLORA DEL TERRENO CULTIVADO Y NO CULTIVADO DE BANAT DEL SUR, SERBIA
}

RESUMEN

Cuatro especies del género Helianthus fueron encontradas en las comunidades vegetales del terreno cultivado y no cultivado en Voivodina y Serbia: $H$. annuus, $H$. tuberosus, $H$. decapetalus y $H$. scaberimus. Las investigaciones realizadas hasta el momento, han demostrado que Helianthus annuus aparece más a menudo en los fitocenosis de malas hierbas. La divulgación de las especies $H$. decapetalus y $H$. scaberimus, introducidas en Voivodina desde los países colindantes, Hungría y Rumania, todavía no ha obtenido escalas alarmantes en el sentido cuantitativo, pero se ha observado la tendencia de continuar su divulgación. Por esta razón es necesario seguir y estudiar la tendencia de su expansión en el período venidero.

\section{Helianthus annuus - UN NOUVEL ÉLÉMENT IMPORTANT DE LA FLORE DU SOL ARABLE ET NON ARABLE DANS LE SUD DU BANAT EN SERBIE}

\author{
RÉSUMÉ
}

Quatre espèces du genre Helianthus ont té trouvées dans les communautés végétales des sols arables et non arables de Voïvodine en Serbie: $H$. annuus, $H$. tuberosus, $H$. decapitus, et $H$. scaberimus. Les études faites jusqu'à maintenant ont montré que Helianthus annuus apparaissait le plus souvent dans les phytocoenoses de mauvaise herbe. Le développement des espèces $H$. decapitus et $H$. scaberimus, introduites en Voïvodine depuis la Hongrie et la Roumanie voisines n'a pas encore pris de proportions alarmantes au point de vue de la quantité mais on a pu observer une tendance vers un développement futur. Il faut donc suivre et étudier cette tendance à l'expansion dans la période à venir. 